\title{
From Concept to Action: Practice and Thinking in Urban Community Development and Community Planning in Chongqing
}

\author{
Ling Huang $^{1 *}$, Yu-Ze Dan ${ }^{1}$, Jian-Feng $\mathrm{Xu}^{2}$, Miao Tong ${ }^{1}$ \\ 1 School of Architecture and Urban Planning, Chongqing University \\ 2 Chongqing BOA Design Institute, Co., LTD. \\ *Corresponding Author, Email: hwawa1025@vip.163.com
}

Received: May 11, 2017; Accepted: Aug 9, 2017

Key words: Community development, Community planning, Community empowerment, Public participation, Planner role, Chongqing

Abstract: Entering an era of a new normal, of emphasizing "people first" and "internalized development", the Chinese urbanization process is shifting from "incremental construction" to "stock management". Therefore, a new approach is required to respond to this change, where urban development is characterized by the slogan, "back to daily life", and problems of urban construction are reviewed on a community scale. Focusing on Yuzhong district, Chongqing, "community development" is a relatively new word. In 2010, the Yuzhong local government improved the regional Community Environmental Renewal and finished it by the end of 2011. Following this, Yuzhong district entered into a phase of urban community development. Based on five different research papers and practical projects in community development between 2010-2015, this paper reviews and analyses the process of community development and community planning in Yuzhong district; the changes reflect the transformation of the demand from urban development on one hand, and the transformation of planning from traditional spatial planning to comprehensive social on the other. Through comparative analysis of key issues, planning objectives, planning ideas, planning strategies, planning methods, public participation, and planning characteristics, this paper proposes starting with community daily life, utilising the community development planning platform to realise idea transformation and action innovation across multiple aspects, such as new methods of knowledge production, community development planning content, community management participation, planner roles, and education.

\section{INTRODUCTION: IMPORTANCE AND URGENCY OF THE COMMUNITY DEVELOPMENT CONCEPT AND ACTION INNOVATION IN CHONGQING}

China's city development has rapidly ushered in a "new normal". Under new conditions, development and innovation is restricted by traditional concepts and behaviours. The new national urbanization strategy prioritises people-oriented development (Qiu, 2012). The Third Plenary Session of the 
18th CPC Central Committee aimed to modernise governance capacity, which required reflection upon the original urban construction concept and mode of development. This was not only a transformation of the national strategy, but also a novel concept for the urban and rural planning discipline. The rapid urbanization of China over the past 30 years places more emphasis on incremental construction than stock development, which leaves a large number of established community assets in cities ignored, or potentially seriously damaged, and further leads to the decline of community identity and the loss of urban characteristics. Ignorance of people and the daily living space of their communities, compounded by a lack of scientific understanding of the value of community assets, is one of the main reasons for these consequences. This and the social and human assets are in fact the basis for the sustainable development of community. As Churchill (1945) said, "The city is the people". Returning the focus to people's daily living space and re-examining the urban construction issue from the social perspective is of paramount importance in dealing with these new changes. Due to the omission of planning content at the community level in the legal urban and rural planning systems of China, it is particularly urgent to explore and summarise the corresponding community theories and planning methods. The factors motivating community development mainly include governmental, market and social forces. In China, traditional community development and construction mainly relies on government. Market forces have appeared gradually in some developed markets, but social forces have remained weak.

Due to geographical, economic and cultural differences, the community development conditions differ between cities and regions in a myriad of ways. Even different communities belonging to the same administrative jurisdiction vary from each other due to the different community structures and construction times. Thus, it is difficult for the Procrustean bed of policies, standards, objectives, planning ideas, methods and implementation strategies of old to effectively solve realistic community issues. Taking Chongqing as an example, in the past 5 years, over 20 million square metres of shantytowns in cities with hidden dangers have been removed, but there are still over 20 million square meters of old communities of moderately good quality, some of which have good locations, spatial features, cultural origins, and traffic accessibility. It is necessary to fulfil the potential of those communities and promote industry exploration, space optimisation, facility optimisation, service innovation, and generally people's livelihoods. Compared with other more developed cities such as Shanghai, Guangzhou and Shenzhen, Chongqing has been lagging behind in community development and planning for nearly 10 years. Chongqing has the typical characteristics of a mountain city. Its urban community is a complex and comprehensive social ecological system. Due to its terrain complexity and multidimensional structure, it has diverse, sensitive, and unique asset values, therefore, it is now urgent to explore the endogenous dynamic mechanisms and planning methods of urban community development in Chongqing to provide a scientific basis for community construction and city regeneration in the future.

After nearly 5 years of continuous urban community planning practice in Chongqing, it has become evident that, in order to achieve community improvement, "community assets" in community development planning significantly include residents' situations and differences. At present, the community development concept of "needs-based" to "asset-based" transformation, promoted by the UN, reflects the notion that the coupling of 
economics and sociology can more effectively promote community development (referred to as ABCD (Phillips \& Pittman, 2009; Huang, 2012). This paper attempts to organise the transformation process of Chongqing's urban community development from concept to action and also explores a community planning method based on the characteristics of local community assets (with the ABCD concept), through to a comprehensive comparison of the community practice projects in Chongqing between 2010 and 2015 .

\section{COMPREHENSIVE COMPARISON AND ANALYSIS OF COMMUNITY PRACTICE IN THE YUZHONG DISTRICT OF CHONGQING OVER THE FIVE YEARS}

This research has been conducted from 2010 until 2015 and is informed by five community planning projects at the three levels of district, street, and community in Chongqing, over four stages of contemporary urban community development and planning, and through an important period of transformation from community-based spatial planning to comprehensive planning of a community-based society (Table 1).

Stage 1 was a cultural renaissance strategy in 2010. The pilot research on the improvement of the living community in the Yuzhong district of Chongqing (Jialingqiaoxicun and Dajingxiang) attempted to use the concepts of cultural capital and social capital to realise spatial and environmental improvement in old communities. It was the first of Chongqing's transformations from a large urban public space to a distinctive daily community living space. Two communities became city-level demonstration points, in which Jialingqiaoxicun was built into the national 3A scenic spot in 2014, after five years of community governance and innovation.

Stage 2 was planning the distribution of vendors' stands on the secondary trunk road and in the back streets of the community in Yuzhong district, Chongqing in 2011. The project emphasised public participation (including governance, urban management personnel, vendors, residents and experts), and acknowledged the existence of the informal economy and the demands of the community's people, allowing for the participation of planners in the development of the community space governance policy and its implementation at the community planning level; this further explored the content and methods of community planning and transformed the role of the planner. The concept of community was thereby established.

Stage 3 was the community development planning of Shiyoulu subdistrict in Yuzhong district, Chongqing in 2013. The project was the first urban community development planning project in Chongqing, in a strict sense. According to the asset-based community development concept, through full investigation of the community assets, it put forward a comprehensive community development and action plan for two levels of community space optimization and the community governance strategy. At the same time, it allowed for the planner to organise public participation in the whole process, which was vigorously supported by community residents.

In 2018, the Minlecun Community Action Plan is being implemented as Minlecun is the demonstration site for community governance innovation in Yuzhong district. This planning process is the beginning of dynamic 
mechanism research on community assets and the application of community planning.

Stage 4 was planning the distribution of sanitation facilities in Yuzhong district of Chongqing, beginning in 2014. Contending with the reality that Yuzhong district can only rely on stock for development, the project begins from the community perspective, and seeks to coordinate the spatial configuration of sanitation facilities and future urban and community space governance together with GIS integration technology and a Chongqing cloud technology platform; it is based on surveys and quantitative analysis of sanitation facilities in Yuzhong district and the community's demands. It is a specific action which applies new ideas, technologies and methods to community research and city stock planning and will be incorporated into detailed regulatory urban planning under the demand of full coverage of urban and rural planning in Chongqing. At the same time, a research project on the economic development and comprehensive improvement of street and lane spaces in three sub-districts, Lianglukou, Shangqingshi and Caiyuanba, began in 2015. This project emphasizes the collaborative development concept of economic development, spatial optimisation and community governance in streets and communities, and explores local paths.

Table 1. Comprehensive Comparison of Community Research and Practice Projects in Yuzhong District of Chongqing between 2010 and 2015: from Spatial Planning to Social Comprehensive Planning

\begin{tabular}{|c|c|c|c|c|c|c|c|c|}
\hline Time & Project & $\begin{array}{l}\text { Main } \\
\text { Problems }\end{array}$ & Planning Goal & $\begin{array}{l}\text { Planning } \\
\text { Concept }\end{array}$ & $\begin{array}{l}\text { Planning } \\
\text { Strategy }\end{array}$ & $\begin{array}{l}\text { Planning } \\
\text { Method }\end{array}$ & Participation & Characteristic \\
\hline 2010 & $\begin{array}{l}\text { Jialingqiaoxic } \\
\text { un and } \\
\text { Dajingxiang } \\
\text { community } \\
\text { renewal }\end{array}$ & $\begin{array}{l}\text { The } \\
\text { community } \\
\text { environment } \\
\text { is dirty and } \\
\text { messy; the } \\
\text { community } \\
\text { culture is } \\
\text { rich but } \\
\text { ignored. }\end{array}$ & $\begin{array}{l}\text { Community } \\
\text { environmental } \\
\text { quality } \\
\text { improvement } \\
\text { based on } \\
\text { cultural } \\
\text { resources }\end{array}$ & $\begin{array}{l}\text { Digging, } \\
\text { demonstration } \\
\text { and utilisation } \\
\text { of community } \\
\text { cultural assets }\end{array}$ & $\begin{array}{l}\text { Construction } \\
\text { of the } \\
\text { community } \\
\text { culture and } \\
\text { community } \\
\text { life line }\end{array}$ & $\begin{array}{l}\text { Real-time } \\
\text { planning and } \\
\text { field design }\end{array}$ & $\begin{array}{l}\text { Government } \\
\text { department, } \\
\text { street, } \\
\text { community, } \\
\text { residents, } \\
\text { experts and } \\
\text { constructors }\end{array}$ & $\begin{array}{l}\text { Research first, } \\
\text { spatial } \\
\text { planning and } \\
\text { design } \\
\text { foremost }\end{array}$ \\
\hline 2011 & $\begin{array}{l}\text { Planning } \\
\text { distribution of } \\
\text { vendors in the } \\
\text { back streets of } \\
\text { communities }\end{array}$ & $\begin{array}{l}\text { A large } \\
\text { number of } \\
\text { mobile } \\
\text { stands affect } \\
\text { the } \\
\text { appearance } \\
\text { of the } \\
\text { cityaesthetic } \\
\text { andit is } \\
\text { difficult to } \\
\text { manage } \\
\text { them. }\end{array}$ & $\begin{array}{l}\text { Promote } \\
\text { mobile stands } \\
\text { as the } \\
\text { movable } \\
\text { cultural } \\
\text { landscape of } \\
\text { the city }\end{array}$ & $\begin{array}{l}\text { Spatial } \\
\text { configuratio- } \\
n \text { of informal } \\
\text { economy }\end{array}$ & $\begin{array}{l}\text { Distribute and } \\
\text { manage } \\
\text { mobile stands } \\
\text { at different } \\
\text { times, areas, } \\
\text { categories and } \\
\text { levels }\end{array}$ & Field planning & $\begin{array}{l}\text { Government } \\
\text { department, } \\
\text { street, } \\
\text { community, } \\
\text { urban } \\
\text { management } \\
\text { personnel, } \\
\text { mobile } \\
\text { vendors, } \\
\text { experts and } \\
\text { residents }\end{array}$ & $\begin{array}{l}\text { Field survey, } \\
\text { space } \\
\text { governance }\end{array}$ \\
\hline 2013 & $\begin{array}{l}\text { Community } \\
\text { development } \\
\text { planning in } \\
\text { Shiyoulu sub- } \\
\text { district }\end{array}$ & $\begin{array}{l}\text { Contradictions } \\
\text { develop } \\
\text { between } \\
\text { economic } \\
\text { development, } \\
\text { community } \\
\text { fairness, and } \\
\text { old and new } \\
\text { community } \\
\text { development; } \\
\text { there is a need } \\
\text { for change in } \\
\text { community } \\
\text { governance. }\end{array}$ & $\begin{array}{l}\text { People- } \\
\text { oriented } \\
\text { community } \\
\text { space } \\
\text { optimization, } \\
\text { and asset- } \\
\text { based } \\
\text { community } \\
\text { governance } \\
\text { upgrading } \\
\text { strategy }\end{array}$ & $\begin{array}{l}\text { Asset-based } \\
\text { community } \\
\text { development } \\
\text { concept }\end{array}$ & $\begin{array}{l}\text { Space } \\
\text { optimization } \\
\text { and } \\
\text { community } \\
\text { governance } \\
\text { upgrading } \\
\text { strategy }\end{array}$ & $\begin{array}{l}\text { Community } \\
\text { asset } \\
\text { investigation, } \\
\text { community } \\
\text { development } \\
\text { planning and } \\
\text { community } \\
\text { action plan }\end{array}$ & $\begin{array}{l}\text { Government } \\
\text { department, } \\
\text { street, } \\
\text { community, } \\
\text { residents and } \\
\text { experts }\end{array}$ & $\begin{array}{l}\text { Trial of } \\
\text { comprehensi } \\
\text { ve planning } \\
\text { of the spatial } \\
\text { aspects of } \\
\text { community } \\
\text { activities }\end{array}$ \\
\hline $\begin{array}{l}2014 \\
- \\
2015\end{array}$ & $\begin{array}{l}\text { Planning } \\
\text { distribution of } \\
\text { sanitation } \\
\text { facilities }\end{array}$ & $\begin{array}{l}\text { Quantity and } \\
\text { quality of } \\
\text { facilities } \\
\text { under the } \\
\text { stock } \\
\text { planning } \\
\text { condition; } \\
\text { non- } \\
\text { identificat-ion } \\
\text { of facility } \\
\text { service }\end{array}$ & $\begin{array}{l}\text { Comprehensi- } \\
\text { vely use and } \\
\text { integrate the } \\
\text { stock facility } \\
\text { resources, } \\
\text { rationally } \\
\text { configure new } \\
\text { facilities, and } \\
\text { efficiently use } \\
\text { the social } \\
\text { facilities }\end{array}$ & $\begin{array}{l}\text { Asset-based } \\
\text { community } \\
\text { development } \\
\text { concept }\end{array}$ & $\begin{array}{l}\text { Effective } \\
\text { social } \\
\text { governance } \\
\text { strategy, } \\
\text { combining } \\
\text { rational } \\
\text { configurati- } \\
\text { on of the } \\
\text { direct } \\
\text { environmen- } \\
\text { tal sanitary } \\
\text { facilities and } \\
\text { open service } \\
\text { of social, } \\
\text { environment } \\
\text { al, and }\end{array}$ & $\begin{array}{l}\text { Investigation } \\
\text { into the } \\
\text { environmental } \\
\text { and sanitary } \\
\text { facility assets } \\
\text { in the } \\
\text { community, } \\
\text { investigation } \\
\text { of people's } \\
\text { demand for } \\
\text { them, and new } \\
\text { facility } \\
\text { planning and } \\
\text { open facilities } \\
\text { in society }\end{array}$ & $\begin{array}{l}\text { Government } \\
\text { department, } \\
\text { street, } \\
\text { community, } \\
\text { residents and } \\
\text { tourists }\end{array}$ & $\begin{array}{l}\text { Starting at } \\
\text { the scale of } \\
\text { community, } \\
\text { combining } \\
\text { with } \\
\text { successful } \\
\text { management } \\
\text { and } \\
\text { including } \\
\text { these } \\
\text { successes } \\
\text { into the } \\
\text { planning } \\
\text { system }\end{array}$ \\
\hline
\end{tabular}




\begin{tabular}{|c|c|c|c|c|c|c|c|c|}
\hline & & & & & $\begin{array}{l}\text { sanitary } \\
\text { facilities } \\
\text { together }\end{array}$ & & & \\
\hline 2015 & $\begin{array}{l}\text { Economic } \\
\text { development } \\
\text { and } \\
\text { comprehensi- } \\
\text { ve } \\
\text { improvement } \\
\text { of street and } \\
\text { lane spaces in } \\
\text { three sub- } \\
\text { districts, } \\
\text { Lianglukou, } \\
\text { Shangqingshi } \\
\text { and } \\
\text { Caiyuanba }\end{array}$ & $\begin{array}{l}\text { Fragmented } \\
\text { and low- } \\
\text { quality urban } \\
\text { street space } \\
\text { and industry }\end{array}$ & $\begin{array}{l}\text { Specific } \\
\text { street } \\
\text { development } \\
\text { positioning, } \\
\text { balance of } \\
\text { street space, } \\
\text { economic } \\
\text { development } \\
\text { and } \\
\text { community } \\
\text { life }\end{array}$ & $\begin{array}{l}\text { Asset-based } \\
\text { community } \\
\text { development } \\
\text { concept }\end{array}$ & $\begin{array}{l}\text { Street space } \\
\text { optimization } \\
\text { and } \\
\text { governance } \\
\text { strategy } \\
\text { focusing on } \\
\text { different } \\
\text { aspects, such } \\
\text { as life, } \\
\text { economy, } \\
\text { landscape and } \\
\text { culture }\end{array}$ & $\begin{array}{l}\text { Street asset } \\
\text { investigation } \\
\text { and field } \\
\text { planning }\end{array}$ & $\begin{array}{l}\text { Government } \\
\text { department, } \\
\text { street, } \\
\text { community, } \\
\text { residents and } \\
\text { tourists }\end{array}$ & $\begin{array}{l}\text { Combination } \\
\text { of spatial } \\
\text { improvement } \\
\text { and } \\
\text { economic } \\
\text { development }\end{array}$ \\
\hline
\end{tabular}

Overall, as the only completely urbanised region in Chongqing, Yuzhong district initially faced the problem of urban stock development. Community is not only a space of mounting problems but also a place for breakthroughs of transformation and innovation. A good community should meet five standards: it should be full of vitality; it should have one or more spaces of assembly or social centres; it should have a collective consciousness; it should have an environment that promotes social and cultural atmospheres that are cherished by the people living in it; and, finally, the ultimate goal of community development, planning and construction, it should be promoted by the people living in it. Yuzhong district government completed the spatial environmental improvement of 72 communities and achieved initial results at the end of 2011, essentially realising the first step of "providing the clean, fresh and vibrant daily living space for residents" (Figures 1 and 2). The distribution planning of mobile stalls should include informal economic activities in the planning of space and have an integrated focus on beauty and harmony through new innovations in urban cultural landscape shaping (Figures 3 and 4). The aim of community development planning is to produce comprehensive sustainable community development strategies that can improve the community environment; community governance services must optimise community space through the planning platform, and gradually carry out and improve it through the action plan (Figure 5 and 6).

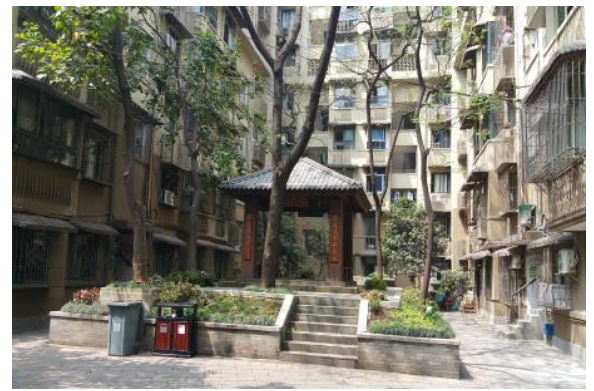

Figure 1: The central garden of Jialingqiaoxicun after the spatial environmental improvement

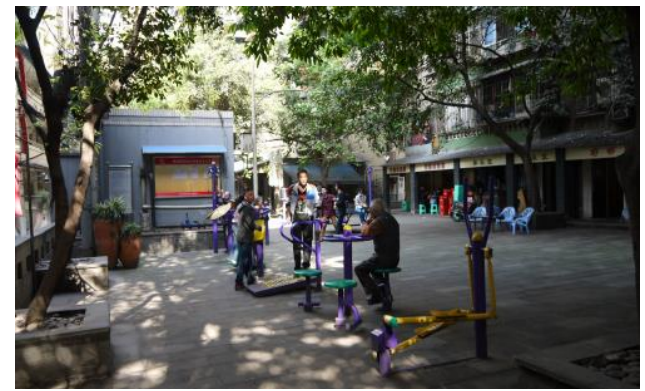

Figure 2: The central square of Dajingxiang after the spatial environmental improvement 


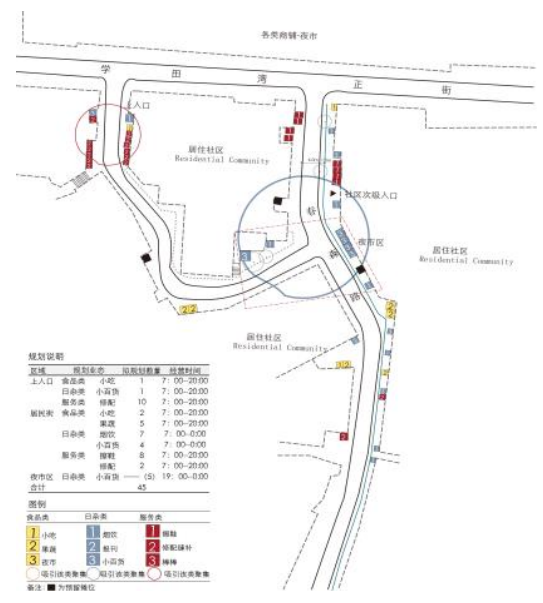

Figure 3: The planned distribution of mobile stalls on Chunsenlu.street

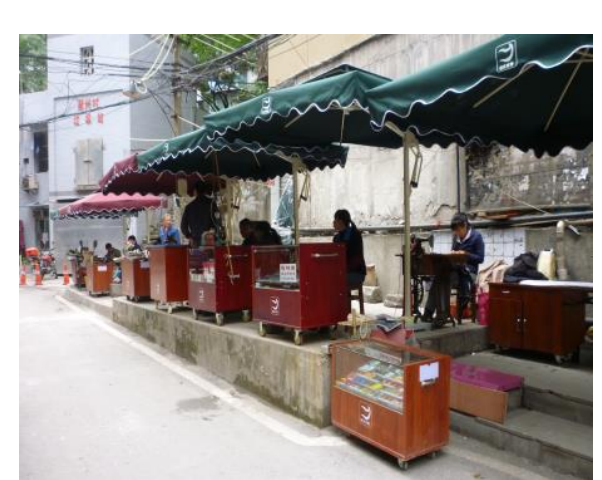

Figure 4: The mobile stalls - city sights on the go.

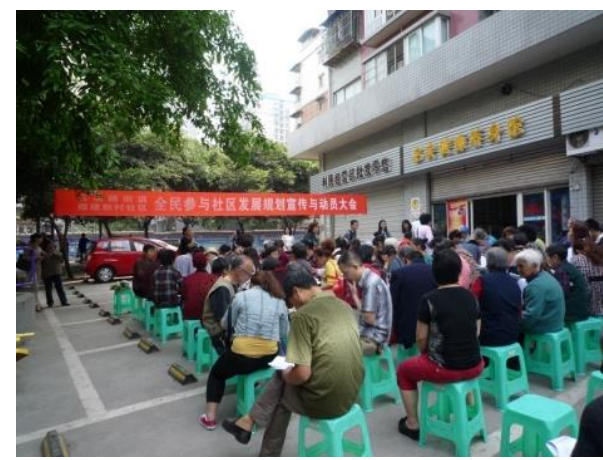

Figure 5: The pep rally of Meijianxincun during Shiyoulu sub-district community development planning.

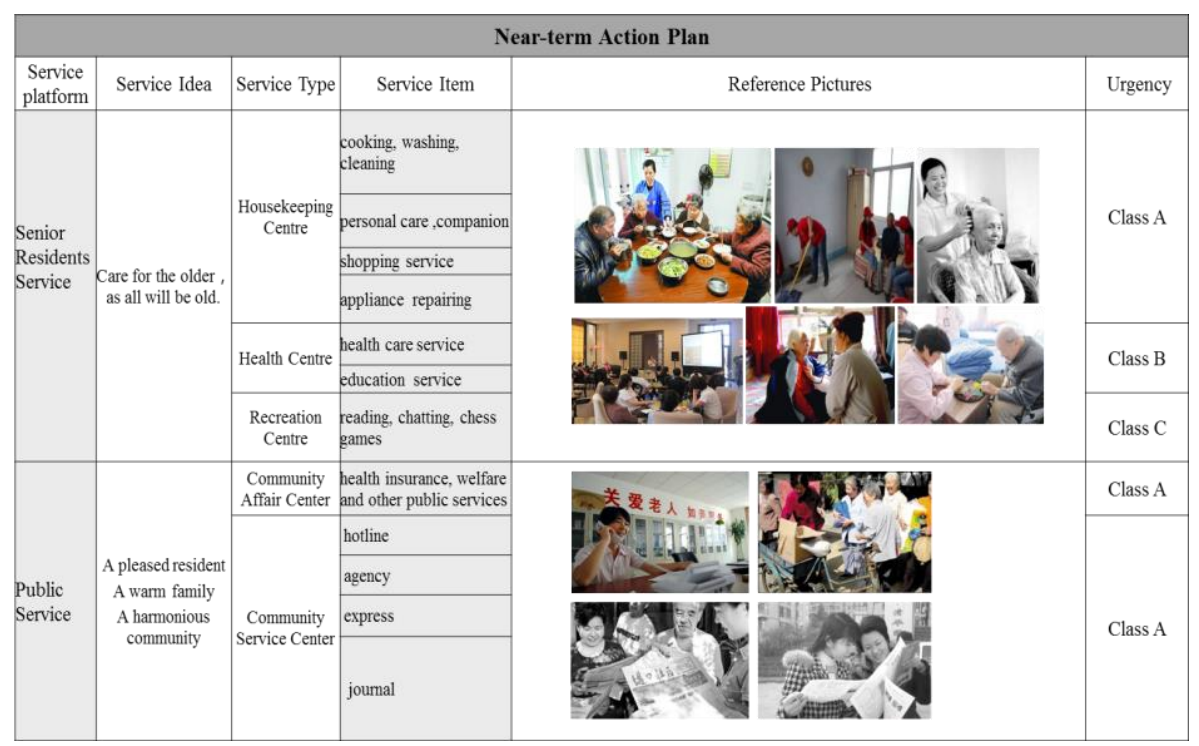

Figure 6: The near-term governance plan of the Minlecun Community Action Plan.

Planning of sanitation facility distribution is the integration and deployment of facility management at the three levels of city, district, and community following the strategies outlined in research on temporal and spatial behaviour based on the existing stock conditions in Yuzhong district; 
it looks at the accessibility of mountain communities, where walking is the standard mode of transport, and appropriately identifies construction land with the aim of maximising social public facilities in order to truly achieve the best coordination of space and policy planning. For three streets in this community, economic development and comprehensive spatial improvement aims at the development of back street economies, treating this as the starting point for improving the vitality of streets and lanes; the development modifies the street landscape with respect to the local culture, associating the space, economies and culture with the regional development of the city and shaping the structural network of related cities at the same time. This is the benefit of comprehensive planning of social space. The five-year community development process is a microcosm of the city development in Yuzhong district. From focusing on material space to social space, from updating concepts to method diversification, to action implementation, it uniquely responds to the time based requirements of shaping a walkable city.

\section{LOCAL THINKING: COMMUNITY CAPACITY BUILDING - FROM CONCEPT TO ACTION}

Throughout the community development and planning processes in China and the West, different countries and regions have their own special national conditions and geographical backgrounds, including at the level of political systems, economies, and cultures. The clear regional differences between communities dictate the necessity and importance of locally relevant community development. A target of sustainable community development is the construction and improvement of the capacity of the community, which is called community capacity building, the process of identifying, protecting, cultivating and constructing community assets. As it is the best method for sustainable community development, community planning should determine planning concepts, methods, content, procedures, organisational form, and achievement evaluation according to the actual situation so as to derive specific strategies and action plans.

\subsection{Concept Transformation: New Interdisciplinary Knowledge Production Mode}

Facing the accelerated normalisation of urban stock development, it is a priority to adapt our thinking and recognise the qualitative change of the new mode of knowledge production (Mode 2), as compared with the traditional mode (Mode 1). The fundamental change has been from a mono-disciplinary to multidisciplinary approach. Although Mode 2 does not completely replace Mode 1, it almost entirely distinguishes itself from Mode 1 in all aspects. In Mode 2, many actors interact with each other closely through the knowledge production process, which means that knowledge production is more socially accountable (Gibbons et al., 1994). Mode 2 lays the foundation for theories and methods to solve complex problems in community development.

Key theories affecting and guiding community development include the social capital theory, functionalism theory, conflict theory, symbolic interaction theory, communicative action theory, rational choice theory, and the structural theory of Giddens (Phillips \& Pittman, 2009). These correspond to the aspects of community development which have been 
emphasised: relation, structure, power, significance of sharing, communication for change, motivation for making decisions and integration of various irrelevant relations and paradoxes.

In 1993, J. Kretzmann and J. McKnight first put forward the "asset-based community development" model (hereinafter referred to as $\mathrm{ABCD}$ ) in the book Building Communities from the Inside Out: A Path toward Finding and Mobilizing a Community's Assets. This presents a positive, outward-looking perspective of the process theory (Phillips \& Pittman, 2009; O'Leary, 2005). Compared with the previous needs-based or deficits-based approach, the $\mathrm{ABCD}$ model begins not from the epistemological problems and needs of community, but from the community's assets or advantages. At the operating level, it does not investigate the community's needs or define the problems first, but identifies the community's assets and advantages with the key work of clarifying a "community capacity inventory" or "community asset map" (Wen \& Huang, 2008; Phillips \& Pittman, 2009; Chaskin et al., 2001; Huang, 2012). The community development strategy is focused on community asset building (Green \& Goetting, 2010). Community assets are divided into three essential forms: physical, human and social assets, where other asset forms can be derived from these (Phillips \& Pittman, 2009; Huang, 2012). Both developed and developing countries actively promote the ABCD model. Practice has proven that it is effective for rebuilding community economies, strengthening social integration, and promoting sustainable development of the community (Sherraden \& Ninacs, 1998; Shaffer, Deller, \& Marcouiller, 2006).

The above theory and "asset-based community development" idea is the theoretical foundation and basis for exploring the local direction of community development and planning in China.

\subsection{Contents of Community Planning: Stock-based, Practical and Feasible}

Firstly, the investigation of community assets focuses on three aspects, namely, community materials, human, and social assets, in order to analyse the spatial distribution of community assets (the community asset map) and obtain the community assets inventory. It is also necessary to investigate the needs of community residents, analyse the problems and development potential of the community on this basis, and, finally, develop the community planning goals and strategy through a dynamic effect analysis and evaluation of community assets.

The second step is the completion of the comprehensive planning of the community, including spatial construction planning and community governance planning, with an emphasis on planning coordination between the optimization and governance of community space.

The last step is the development of the community action plan and gradual implementation of the goal of comprehensive planning of the community through partitions, pilots and other forms. Regarding the case of Chongqing, it is recommended the comprehensive community planning be completed at the street level and scope the action plan to the level of community jurisdictions, which will help the overall systematic management of spatial optimisation and integrated management, producing facilitates reflecting the differences and characteristics of each community in the action plan (Huang \& Luo, 2014). 


\subsection{Public Community Participation: Discover and Cultivate the Human Community Assets and Participate in Community Governance}

Community governance must organize and implement public participation, fully cultivate and give play to the positive role of community organisation, and participate in the entire process from initial community planning mobilisation meetings to community asset investigation, so as to truly realise the collaboration between government departments, streets communities, residents, and experts. The difficulty of public participation management lies in the the degree and timing of participation, which directly relates to its efficacy. At the same time, cultivating the residents' ability to participate in the community governance should be a priority of the community development planning goals. Jialingqiaoxicun's success with autonomous management and community volunteers provides a good model for the sustainable development of communities in Chongqing.

\subsection{Transformation of the Planner's Role and Community Planners' Education: Entering into the Community to provide Real-time Planning}

When a city enters the stage of stock development, it is inevitable for the planner to transform from the role of blueprint planner to an action planner. At this time, the concepts, working contents, and working methods are all updated with an emphasis on field investigation, negotiation, and cooperation (Yu \& Cao, 2013; Huang \& Xu, 2013; Zhao, 2013). The community planner should be recognised as a general practitioner in the community who has a rich and comprehensive knowledge about the community, as well as planning skills and a desire to develop the values of social fairness and justice; they should be enthusiastic about serving the people through effective communication. The training and education of community planners can be carried out at two levels, through university and vocational school, or through experience in the community.

\section{CONCLUSION AND PROSPECTS}

It should be said that the direction of Chongqing's community planning is just the beginning. Compared with more developed cities in China, such as Shanghai, Guangzhou and Shenzhen, it is 10 years behind; yet this positively reflects on the economic level of the city. Circumstantially, Chongqing is forced to seek a regeneration path at the scale of the community; however, due to the lack of experience in relevant knowledge structures and practices, learning must take place alongside planning so as to expedite the exploration of theories and methods suitable for community development and planning in each locale. At the same time, community planning has a commonplace worldwide, namely, within the government power structure. This is no exception even in the United States, where community planning is characterized by the bottom-up approach ( $\mathrm{Li}, 2013)$. At present, one of the characteristics of China's community development and planning is the government's dominant role, which is likely to exist for a long time. The 
advantage of this mode of planning is that the government is able to provide strong external support for the community, allowing for rapid change, however, there are some clear disadvantages, such as the non-sustainability and residents' excessive dependence on the government, which weakens their initiative and growth opportunities, minimising their participation in community governance. Moreover, China's community is more a concept of administrative community under the jurisdiction of the community residents' committee (Liu, 2013), which is very different from the sociological understanding of community. Thus, at present, for the process of community development and planning, the contradiction of non-coincidence between the social boundary and governance boundary of community is an innate shortcoming in realising the goal of a quality living community.

Despite the existence of various problems and contradictions, since community complexity is also a part of social complexity, a view of development should be taken of its capacity to alleviate the problems of the future community, to identify and activate community assets, to aim towards cultivating and increasing community capacity, and to transition from dependence on government power and market forces outside the community to dependence on the benign development of the asset power in the community, so as to truly realise the best path for sustainable community development ; this approach combines the top-down and bottom-up approaches together. Developing this community practice from concept to action elevates the concept to a new level, which is valuable for its epistemological significance and practical guidance, moving society towards a more advanced stage of socialism.

\section{ACKNOWLEDGEMENT}

This paper is supported by National Natural Science Foundation of China (No. 51778078) and Natural Science Foundation of Chongqing (No. cstc2015jcyjA00051)

\section{REFERENCE}

Chaskin, R. J., Brown, P., Venkatesh, S., \& Vidal, A. (2001). Building Community Capacity. New York: Aldine de Gruyter.

Churchill, H. S. (1945). The City Is the People. New York: Reynal \& Hitchcock.

Gibbons, M., Limoges, C., Nowotny, H., Schwartzman, S., Scott, P., \& Trow, M. (1994). The New Production of Knowledge: The Dynamics of Science and Research in Contemporary Societies. London: SAGE Publications Ltd.

Green, G. P., \& Goetting, A. (Eds.). (2010). Mobilizing Communities: Asset Building as a Community Development Strategy. Philadelphia: Temple University Press.

Huang, L. (2012). "From Needs-Based to Asset-Based-Inspiration from Contemporary Community Development in Us". Interior Design, (5), 3-7.

Huang, L., \& Luo, Y. (2014). "Community Development Planning and Other Methods Form a New View of Social Governance - a Case Study on Community Development Planning of Shiyoulu Street in Chongqing's Yuzhong District". Journal of Human Settlements in West China, (5), 13-18.

Huang, L., \& Xu, J. (2013). "Research on Value Fundament and Role-Making of City Community Planner System". Planners, (9), 11-16.

Li, D. (2013). "Community Development History and Experience of American". Urban Problems, (2), 89-92. 
Liu, J. (2013). Contemporary China City. Nanjing: Southeast University Press.

O'Leary, T. (2005). "Asset Based Approaches to Rural Community Development: Literature Review and Resources": Seminar Report by International Association for Community Development for Carnegie UK Trust.

Phillips, R., \& Pittman, R. (2009). An Introduction to Community Development. New York: Routledge.

Qiu, B. (2012). "New Urbanization: From Concept to Action". Administration Reform, (11), 11-18.

Shaffer, R., Deller, S., \& Marcouiller, D. (2006). "Rethinking Community Economic Development". Economic Development Quarterly, 20(1), 59-74.

Sherraden, M. S., \& Ninacs, W. A. (1998). Community Economic Development and Social Work. Binghamton: The Haworth Press.

Wen, J., \& Huang, R. (2008). "On Asset-Based Community Development Strategy and the Enlightenment to China". Journal of Social Science of Hunan Normal University, 37(6), 74-78.

Yu, Y., \& Cao, C. (2013). "Community Planning and Management Innovation". Planners, (3), 5-10.

Zhao, W. (2013). "Discussion About the Fundament of Community Planning System and the Role of Community Planners". Planners, (9), 17-21. 